\title{
Deficiency of the infundibular septum in patients with Interrupted aortic arch and del 22q11
}

$\mathrm{W}$ READ WITH INTEREST THE PAPER OF Momma et al. concerning interruption of the aortic arch in association with deletion of chromosome $22 \mathrm{q} 11 .^{1}$

In 6 of the 7 patients with this association the authors reported 'a complete deficiency of the muscular outlet septum with the defect extending to the perimembranous area'. Since the subarterial and doubly committed ventricular septal defect is prevalent in the oriental populations, ${ }^{2}$ Momma et al. suggest that 'It remains to be confirmed if the association of the specific type of defect seen with interrupted aortic arch between the left common carotid and the left subclavian arteries and deletion of chromosome $22 \mathrm{q} 11$ is present in Caucasians'.

Contemporany to the paper of Momma et al., ${ }^{1}$ we published a study on the same topic involving analysis of Italian patients. ${ }^{3}$ Among 13 children with interruption of the aortic arch between the common carotid and subclavian arteries, and with deletion of chromosome $22 \mathrm{q} 11$, we detected in 9 patients the same pattern of ventricular septal defect, in which there was complete absence of the muscular outlet septum. We can conclude that this type of ventricular septal defect, previously reported in patients with interrupted aortic arch, ${ }^{4,5}$ is characteristic of the specific combination of the site of interruption and deletion of chromosome $22 \mathrm{q} 11$ in spite of the racial differences.

Hypoplasia or absence of the muscular outlet septum has also been reported to be prevalent in patients with tetralogy of Fallot and deletion of chromosome $22 \mathrm{q}^{1} 1^{6,7}$ suggesting that a specific disturbance of the infundibular musculature is very frequent in this genetic syndrome. ${ }^{8}$ In fact, the muscular outlet septum is hypoplastic or absent in other malformations of the ventricular outflow tracts associated with deletion of chromosome $22 \mathrm{q} 11$, including common arterial trunk, tetralogy with pulmonary atresia, ${ }^{10}$ and in some patients with isolated ventricular septal defects (unpublished observation).

Recently, Yamagishi et al., ${ }^{11}$ studying the expression of a new gene that our group previously identified, ${ }^{12}$ reported that 'UFD $1 \mathrm{~L}$ expression was most evident in the fourth aortic arch artery which is responsible for formation of the segment of the aortic arch that lies between the left carotid and subclavian arteries'.

As pointed out in the editorial comment of McElhinney and Anderson, ${ }^{13}$ and in agreement with these new anatomic and genetic observations, we suggest that in cases where the aortic arch is interrupted between the left carotid and subclavian arteries the hypothesis of a pathogenetic role of subaortic obstruction ${ }^{5-14}$ has lost value.

\section{B. Marino, M.C. Digilio, A. Toscano, B. Dallapiccola "Pediatric Cardiology and Genetics" Bambino Ges-Hospital Roma Italy}

\section{References}

1. Momma K, Ando M, Matsuoka R, Joo K. Interruption of the aortic arch associated with deletion of chromosome $22 \mathrm{q} 11$ is associated with a subarterial and doubly committed ventricular septal defect in Japanese patients. Cardiol Young 1999; 9: 463-467.

2. Ando M. Subpulmonary ventricular septal defect with pulmonary stenosis (letter). Circulation 1974; 50:412.

3. Marino B, Digilio MC, Persiani M, Di Donato R, Toscano A, Giannotti A, Dallapiccola B. Deletion 22q1 1 with interrupted aortic arch. Am J Cardiol 1999; 84: 360-361.

4. Freedom RM, Esplugas E, Dische R, Rowe R. Ventricular septal defect in interruption of aortic arch. Am J Cardiol 1977; 39: $572-582$.

5. Al-Marsafawy HM, Redington AN, Anderson RH. The relationship of the outlet septum to the aortic outflow tract in hearts with interruption of the aortic arch. J Thorac Cardiovasc Surg 1995;109: 1225-1236.

6. Marino B, Digilio MC, Grazioli S, Formigari R, Mingarelli R, Giannotti A, Dallapiccola B. Associated cardiac anomalies in isolated and syndromic patients with tetralogy of Fallot. Am J Cardiol 1996; 77: 505-508.

7. Momma K, Kondo C, Ando M, Matsuoka R, Takao A. Tetralogy of Fallot associated with chromosome 22q11 deletion. Am J Cardiol 1995; 76: 618-621.

8. Marino B, Digilio MC, Toscano A, Giannotti A, Dallapiccola B. Congenital heart defects in patients with DiGeorge/Velocardiofacial syndrome and del 22ql 1. Genet Couns 1999; 10: 25-33.

9. Momma K, Ando M, Matsuoka R. Truncus arteriosus communis associated with chromosome $22 \mathrm{q} 11$ deletion. J Am Coll Cardiol 1997; 30: 1067-1071. 
10. Digilio MC, Marino B, Grazioli S, Agostino D, Giannotti A, Dallapiccola B. Comparison of occurrence of genetic syndromes in ventricular septal defect with pulmonic stenosis (classic tetralogy of Fallot) versus ventricular septal defect with pulmonic atresia. Am J Cardiol 1996; 77: 1375-1376.

11. Yamagishi H, Garg V, Matsuoka R, Thomas T, Srivastava D. A molecular pathway revealing a genetic basis for human cardiac and craniofacial defects. Science 1999; 283: 1158-1161.

12. Pizzuti A, Novelli G, Ratti A, Amati F, Mari A, Calabrese G, Nicolis S, Silani V, Marino B, Scarlato G, Ottolenghi S,
Dallapiccola B. UFD1L, a developmentally expressed ubiquitination gene, is deleted in CATCH 22 syndrome. Hum Mol Genet 1997; 6: 259-265.

13. McElhinney DB, Anderson RH. Development anomalies of the outflow tracts and aortic arch: towards an understanding of the role of deletions within the 22nd chromosome. Cardiol Young 1999; 9: 451-457.

14. Moore GW, Hutchins GM. Association of interrupted aortic arch with malformation producing reduced blood flow to the fourth aortic arches. Am J Cardiol 1978; 42: 467-472. 